\title{
LabVIEW-Based Learning Media for Instrumentation Control Systems and Automation Process Subject at SMK Negeri 1 Cimahi
}

\author{
Khaesa Ananda Putri, Yoyo Somantri, Wawan Purnama* \\ Universitas Pendidikan Indonesia \\ Bandung, Indonesia \\ khaesaaputri.17@student.upi.edu,ysomantri@upi.edu,*wawan_purnama@upi.edu
}

\begin{abstract}
In this era, automation technology and industrial control systems is being developed rapidly without being matched by adjustments in the field of education. The usage of electronic software can be a solution in the field of education for the learning process, therefore the educational curriculum can be in line with industry needs at a lower price. One of the electronics software that can be applied as control system and industrial automation is NI LabVIEW. At SMK Negeri 1 Cimahi, none of learning media is available for the subject of Instrumentation Control Systems and Automation Process, especially in the basic competencies of implementing the LabVIEW software in the instrumentation field. This present research aims at, (1) making BALISTIK as a learning media for the subject of Instrumentation Control Systems and Automation Process; (2) knowing the eligibility level of BALISTIK; and (3) knowing the response of the BALISTIK user. Performance is measured by functional testing activities while the level of feasibility is observed from the assessment results of material and media experts, limited test is carried out by means of two students using learning media directly and students working on evaluation questions, as much as 34 students provides user's response by online which is seen from the user questionnaire results after the user sees the BALISTIK demonstration video along with the learning module that has been made. The results of this study indicated that BALISTIK has a good performance. From the limited test results of BALISTIK, it was concluded that BALISTIK was appropriate to be used as a learning media. Besides, based on the data analysing result, it occurred that user gave a positive response towards the learning media. Thus, BALISTIK was suitable as a learning media for the subject of Instrumentation Control Systems and Automation Process.
\end{abstract}

Keywords-BALISTIK, learning media, LabVIEW, instrumentation control systems and automation

\section{INTRODUCTION}

Learning media is a thing that can be used to stimulate students' thoughts, feelings, attention and abilities or skills. Learning media is one of the important elements in schools to support the educational process. By using the media, educators' intention of everything that they want to convey will be easily understood. Nowadays, technology can be utilized as a learning media. Currently, the role of technology is widely used in the education field [1]. The utilized of media in learning can generate new desires and interests, motivation and stimulation of learning activities, even it can influence students psychologically [2]. The research results also showed that the use of instructional media can improve student interest and learning outcomes [3].

SMK Negeri 1 Cimahi is the only vocational high school in Indonesia that teaches about competency skills of Instrumentation and Automation Process. Based on the observations of Instrumentation competency skills and Automation Process, for the subjects of Control Systems Instrumentation and Automation process with the Basic Competence of the application of Electronic LabVIEW Software for Programming and Control System Simulation Process, it was found a practical problem in the learning process on that basic of competence. The learning process only uses a simple learning media in the form of simulation software to support basic learning of this subject. Thus, students become less motivated in learning due to this simple learning media.

It becomes an urge need of a low-cost learning media in order to optimize the learning process [4]. Low-cost learning media can create a variety of teaching aids, so that the learning environment becomes more effective, interesting and interactive. The use of the Arduino microcontroller for educational purposes is considered quite effective to increase students' interest and learning outcomes even though it used only at a limited cost [5]. LabVIEW is a software for graphical programming, unlike the common programming languages which are generally in the form of text-based, LabVIEW uses certain symbols as a programming language [6].

Based on the findings and studies that have been described, it is necessary to have a learning media that can support the learning process for the subject of Instrumentation Control Systems and Automation Process, and can improve students' motivation and understanding in learning. Based on this background, the researchers made a learning media in the form 
of training modules or ATMega328 microcontroller-based of LabVIEW trainers which is called the Basic LabVIEW Instrumentation Training Kit (BALISTIK). This is based on the need for LabVIEW trainers who require competency skills in Instrumentation and Automation Process at SMK Negeri 1 Cimahi. On the other hand, this BALISTIK needs to be implemented in order to know the response of students regarding BALISTIKS itself. Thus, the researchers conducted a research titled "The Production of LabVIEW-based Learning Media for the Subject of Control Systems Instrumentation and Automation Process at SMK Negeri 1 Cimahi". This study aims to (1) design BALISTIK learning media for students in the subject of Control Systems Instrumentation and Automation Process in terms of their performance; (2) Know the results of the feasibility test of BALISTIK learning media for students in the learning of Control Systems Instrumentation and Automation Process; (3) Know the response of students towards BALISTIK learning media in learning Control Systems Instrumentation and Automation Process at SMK Negeri 1 Cimahi.

\section{METHODS}

\section{A. Research Design}

This research uses quantitative methods, so the data in the study are presented in numerical form which represents respondents' response. The development model used in this research is ADDIE model. ADDIE is the acronym for Analyze, Design, Develop, Implement, and Evaluate [7]. ADDIE is a development research model suitable for creating and developing learning products. ADDIE model used in this study was adopted from Liu et al. research [8]. Hence, this study has the procedure stage as follows:

1) Analysis: In the analysis stage, the researcher conducted the observations at SMK Negeri 1 Cimahi, conducted interviews with teachers, and performed the documentation studies. The obtained result was the information on the need for learning media in the form of training modules or trainers for the lessons on Control Systems Instrumentation and Automation Process with the basic competencies of using LabVIEW electronic software in the field of instrumentation. The results were analysed so that the products can be made in accordance to the learning needs.

2) Design / Planning: The second stage is designing or planning, the researcher designed the trainer which was equipped with a manual for its use as needed at the analysis stage. The trainer design was equipped with a schematic circuit.

3) Development: The third stage is the development stage. At this stage the researchers made trainers and manuals according to the design at the design stage. After the trainer was made, a functional test was carried out to test the performance before it was given to the media experts, material experts and students. Furthermore, expert judgment was carried out on media experts in order to determine the appropriateness of this teaching aid, while expert judgment was carried out on material experts to determine the feasibility of the learning module. The results of expert judgment were also used as a basis for product revision if necessary.

4) Implementation: The fourth stage is implementation, at this stage the researchers tested the instructional media products to two students of the Instrumentation and Automation expertise competency, and then students filled out the worksheet. Testing was also carried out on 34 other students by presenting demonstration videos and learning modules, followed by filling out a questionnaire that had been prepared via google form. All of the test participants were students from class XII who were taking the Control System and Automation Process.

5) Evaluation: Furthermore, the last stage is the evaluation, at this stage the researcher obtained the results from the questionnaire of feasibility filled out by material experts, media experts, and users or students. Evaluation was done using Likert scale, so that researchers can conclude the feasibility of the products that had been made.

\section{B. Participants and Research Sites}

Participants in this study were selected by purposive sampling with consideration in accordance with the research objectives, which were media experts, material experts, and students. 1 (one) media expert who is one of the lecturers of learning media courses at DPTE UPI. There are 3 (three) material experts who are one of the lecturers at DPTE UPI and one teacher in the Instrumentation and Automation Process competency expertise at SMK Negeri 1 Cimahi. As well as 36 students of competency skills in Instrumentation and Automation Process at SMK Negeri 1 Cimahi.

\section{Data Collection Techniques}

The data collection techniques used in this research were observation, literature study, documentation study, and research questionnaire. Literature study was carried out by reading books and some literature related to the research undertaken. Observation was conducted by observing the surrounding environment directly and the availability of learning facilities and infrastructure, one of which is learning media. Documentation study was carried out by analysing all documents related to the research problem. Research questionnaire was distributed by giving a set of questions to the respondent to be answered. The type of questionnaire used was a closed questionnaire where the answer is available so that the respondent can choose the answer to each question directly.

\section{Research Instruments}

The instrument used in this study was a questionnaire sheet. This type of questionnaire was a closed questionnaire which already has the answer to each item of the question. This questionnaire was given to material experts, media experts and respondents or users -students of XII class of the competency 
skills of Instrumentation and Automation Process at SMK Negeri 1 Cimahi. In the limited trial, three aspects were tested which were cognitive, affective, and psychomotor aspects. Cognitive aspect testing was done by giving multiple choice questions to students that have a maximum value of 100 points, then for the affective and psychomotor aspects testing were filled in by researchers who aim to measure the feasibility of the media after limited trials were carried out on students who had used the products of learning media.

\section{E. Data Analysis Techniques}

This present research used descriptive statistical techniques for the data analysis technique. This technique is a method used in analysing data by describing or picturing the data obtained without drawing general conclusions [9]. There were several steps taken in analysing the data using this technique, including calculating the value of the respondent's instrument, calculating the average value, and calculating the percentage of user responses.

\section{RESULTS AND DISCUSSION}

\section{A. Research Results}

1) Analysis: At this stage the researcher collected and analysed the information obtained, thus researchers can find out the problems of teaching and learning activities for the needs of product design in the subject of Control Systems Instrumentation and Automation Process.

2) Observation: The researcher conducted an observation by providing observation sheets to the teacher of Control System Instrumentation and Automation Process subject in order to identify and analyse the learning needs of these subjects. The observation results indicated that there was a problem with the understanding of the material regarding the usage of LabVIEW software in the instrumentation field. Therefore, researchers planned to produce a product of BALISTIK learning model equipped with its learning modules.

3) Syllabus analysis: There were 22 Basic Competencies (KD) in the syllabus of the Control System Instrumentation and Automation Process subject, all of basic competencies were divided into 22 weeks/meetings. The product developed by the researcher was based on KD 2 in the 3rd meeting.

\section{B. Design (Planning)}

1) Media design: The flow of training kit development is represented through a flowchart. The flowchart makes simplify the researchers to do the process of designing training kit, the flowchart is shown in Figure 1 below.
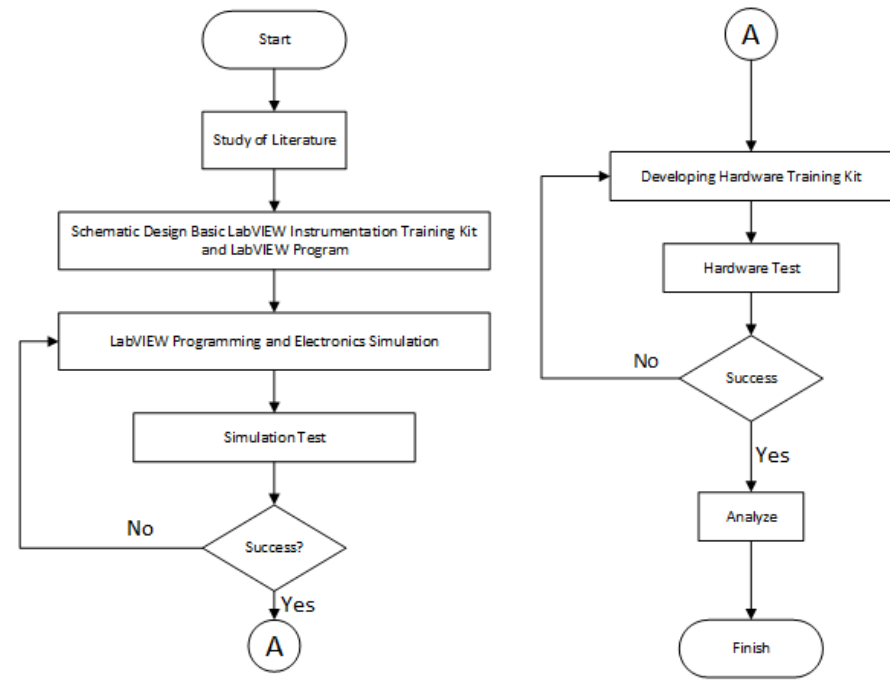

Fig. 1. Flowchart of media design.

2) Analysis of BALISTIK block diagram: To simplify the analysis of how the training kit works, it was done by making a block diagram of training kit first. This block diagram is the basic reference in designing the training kit series scheme. The block diagram is shown in Figure 2 below.

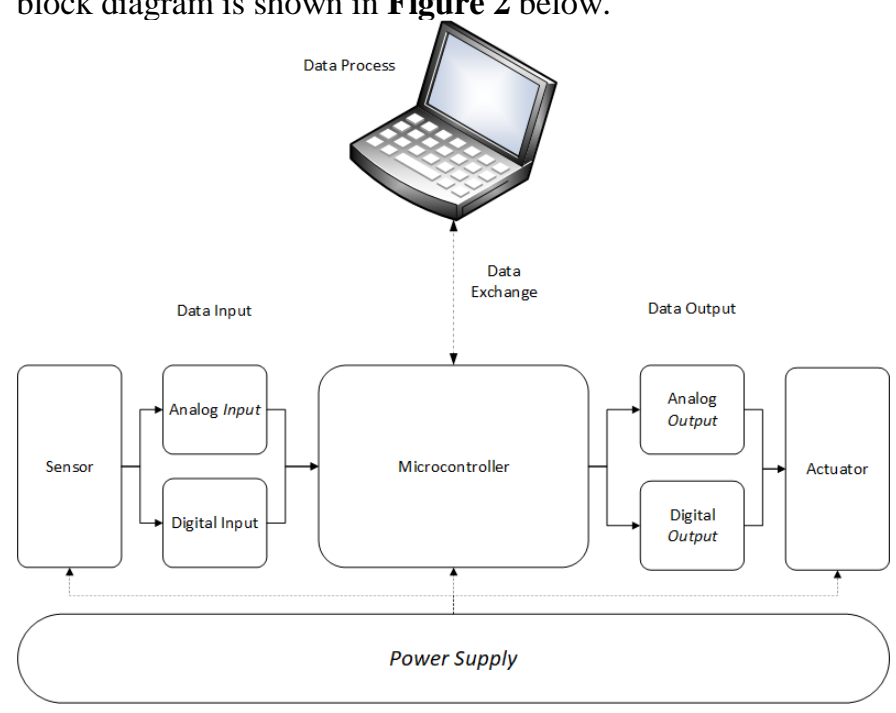

Fig. 2. Block diagram of BALLISTIC mechanism.

3) The design of learning module: In the learning module, the researcher designed the framework content that will be used in the module. The content outline were (1) cover page; (2) preface; (3) table of contents; (4) list of tables; (5) list of figures; (6) product reviews (7) safety guidelines; (8) specific guidelines for product use; (9) theoretical basis; and (10) worksheets. 


\section{Development}

1) The production of BALISTIK: At this stage, the fabrication process was carried out starting from the schematic design of electronic circuits, PCB layout design, PCB manufacturing, and component soldering process on the PCB. The manufacturing result is shown in Figure 3.

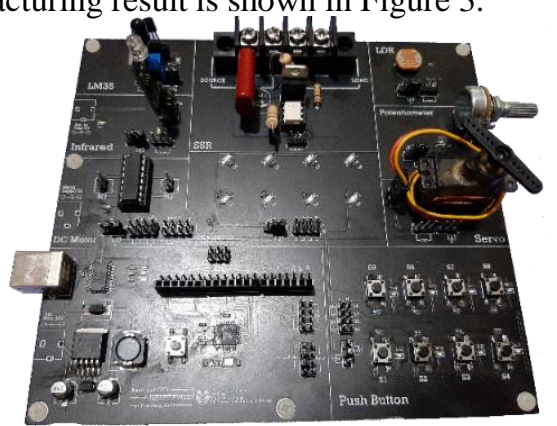

Fig. 3. BALISTIK learning media.

2) The production of learning modules: The learning module for BALISTIK learning media was made according to the results at the design stage. The cover page of the learning module is shown in Figure 4.

MODUL PEMBELAJARAN BASIC LABVIEW INSTRUMENTATION TRAINING KIT

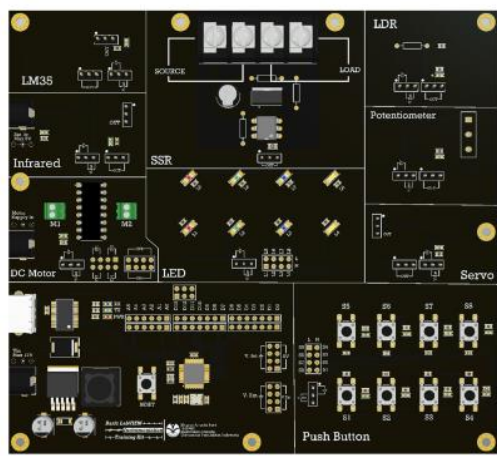

$$
\begin{gathered}
\text { DISUSUN OLEH: } \\
\text { Khaesa Ananda Putri } \\
\text { Drs. Yoyo Somantri, S.T., M.Pd. } \\
\text { Wawan Purnama, S.Pd., M.Si. }
\end{gathered}
$$

PROGRAM STUDI PENDIDIKAN TEKNIK ELEKTRO FAKULTAS PENDIDIKAN TEKNOLOGI DAN KEJURUAN UNIVERSITAS PENDIDIKAN INDONESIA
3) Functional test: The functional test was done to determine the learning media performance by ensuring that no errors occurred when it was operated, which the errors might hinder the use of learning media. The results of functional test is shown in Table 1. Based on the results of functional tests, it can be concluded that the design of BALISTIK learning

\begin{tabular}{|c|c|c|}
\hline No & Block Name & $\operatorname{Error}(\%)$ \\
\hline 1 & Power Socket & 0 \\
\hline 2 & Power Indicator & 0 \\
\hline 3 & Push Button & 0 \\
\hline 4 & Potensiometer & 0 \\
\hline 5 & LDR & 0 \\
\hline 6 & LM35 & 0 \\
\hline 7 & Infrared & 0 \\
\hline 8 & Mikrokontroler & 0 \\
\hline 9 & USB Indicator & 0 \\
\hline 10 & LED Output Indicator & 0 \\
\hline 11 & Motor Micro Servo & 0 \\
\hline 12 & DC Motor Driver & 0 \\
\hline 13 & Solid State Relay & 0 \\
\hline
\end{tabular}
media had a good performance because none of the error was found in each of its components.

TABLE I. FunCTIONAL TEST RESUlts

\section{4) Feasibility testing of the product}

a) The result of expert testing: Based on the results of expert testing, this learning media was feasible to be applied in the field from the aspects of its materials and graphics, performance aspects, and benefits aspects. The aspects of material and graphic were declared feasible with a final percentage value of $60 \%$, because the media had the appropriate size to be applied in the classroom. The selected material met the principle of harmlessness, and was able to operate as expected. This learning media design was said to be good because it had a nice layout component. The performance aspect was signified to be feasible with a final percentage value of $60 \%$, because the way this learning media works had fulfilled its features and was easy to use by users. The benefit aspect obtained a final percentage value of $75 \%$ in the proper category, since this learning media was considered capable of providing learning for users and increasing user motivation. Based on the results of expert tests on material experts, the learning module for BALISTIK received a very decent

Fig. 4. The cover page of learning module. 
predicate with an average percentage of $87.43 \%$. Overall, this learning media and learning module got the predicate of the feasible category due to its function which was in accordance with the planned features, as well as a learning module that supported the use of media and was in accordance with the intellectual and emotional development of students.

b) Product revisions: After obtaining data regarding the feasibility of this media, revisions were made according to the data obtained. Revisions were made in both the learning module and learning media. Revisions made to the learning module was included adding questions / exercises to each jobsheet, correcting the imperative sentences, and correcting the truncated part of the jobsheet 10 . Furthermore, the revision made on the Basic LabVIEW Instrumentation Training Kit learning media aimed to improve the unclear volume of the video on the explanation of the training kit.

\section{Implementation}

The implementation of this research was carried out in two ways, the first was an assessment of the training kit by 34 students of XII class of the competency skills of Instrumentation and Automation Process at SMK Negeri 1 Cimahi. Due to the condition of Indonesia which was facing the Covid-19 pandemic, the assessment was carried out through online, by means of which students were given a demonstration video of a training kit, and a BALISTIK learning module. Then students were allowed to fill out a questionnaire distributed via google form to get the data regarding the training kit and learning module feasibility from the user's point of view. The second way was with a limited trial of two students who had the same skill and competency level. Limited testing was done by providing the products of learning media (Training Kit and learning modules) to the respondent, then the respondent answered the questions from the cognitive aspects instruments that had organized by researchers, and got the assessment for affective and psychomotor aspects from the researcher who served as observer.

\section{E. Evaluation}

The evaluation in this study was carried out by processing the data obtained from the feasibility test of the media, materials, and also from user assessment data collected from 36 students of the competency skills of Automation Process Instrumentation at SMK Negeri 1 Cimahi. User response data assessed three aspects, as follows (1) the usage of the module; (2) the usage of the media; and (3) the learning. The module usage aspect obtained the percentage value of $80.55 \%$ and categorized as very useful. The media usage aspect obtained the percentage value of $80.44 \%$ and categorized as very useful. Besides, it was found that the final result was the user rating average value of $80.51 \%$ and it was included in the very useful category. The results of the limited trial of two students revealed that if it viewed from a cognitive aspect, students were able to understand all material from learning media products since it was obtained the cognitive assessment score of 90 for respondent 1 , and 100 for respondent 2 . For the affective and psychomotor assessment results, it can be concluded that students' abilities and attitudes in practicum were classified as very good, in terms of the observation results when students did practicum in this limited test.

\section{CONCLUSION}

Based on the findings and discussion that had done by the researcher, the researcher concluded that the BALISTIK had a good performance as shown by the functional test results which produced an error of $0 \%$. Furthermore, based on the results of the assessment from material experts, the eligibility level of BALISTIK was categorized as very feasible to be applied to the Control Systems Instrumentation and Automation Process subject. Meanwhile, based on the results of the assessment from media experts, the feasibility level of BALISTIK was categorized as feasible to be applied to the Control Systems Instrumentation and Automation Process subject with a percentage of $87.43 \%$ from the feasibility assessment of material experts and $64.00 \%$ from media experts. Further, it was obtained the user response after a limited trial assessment which the learning media was very good to be applied as a learning media in terms of the assessment results of cognitive, affective and psychomotor aspects. The responses from the user through a google form questionnaire indicated that the training kit was stated very useful to be applied as a learning media for the subject of Control Systems Instrumentation and Automation Process at SMK Negeri 1 Cimahi with the assessment percentage of $83.30 \%$.

\section{REFERENCES}

[1] Ameliola, Perkembangan Media Informasi dan Teknologi terhadap Anak dalam Era Globalisasi. Malang: Universitas Brawijaya, 2013.

[2] A. Arsyad, Media Pembelajaran. Jakarta: Rajawali Pers, 2015.

[3] P. Plaza, E. Sancristobal, G. Fernandez, M. Castro, and C. Perez, "Collaborative robotic educational tool based on programmable logic and Arduino," Proc. 2016 Technol. Appl. to Electron. Teaching, TAEE 2016, 2016.

[4] A.G. Abdullah, D.L. Hakim, M.A. Auliya, and M.A. Fahrurizal, "Preliminary Design of Industrial Automation Training Kit Based Real Mobile Plant," no. Icaet, pp. 133-135, 2014.

[5] M.R.S.B. Souza, J.J.P.Z. Tavares, J.F. Ribeiro, and R.R. Rocha, "Design, Manufacture and Construction of a Wireless Robotic Arm for Educational Purposes," Proc. - 12th LARS Lat. Am. Robot. Symp. 3rd SBR Brazilian Robot. Symp. LARS-SBR 2015 - Part Robot. Conf. 2015, pp. 376-380, 2016.

[6] P. Spanik, L. Hargas, M. Hrianka, and I. Kozehuba, "Application of virtual instrumentation lab VIEW for power electronic system analysis," EPE-PEMC 2006 12th Int. Power Electron. Motion Control Conf. Proc., pp. 1699-1702, 2007

[7] R.M. Branch, Instructional Design : The ADDIE Approach. New York: Springer, 2009.

[8] W.T. Liu, E.Z.F. Kou, C.H. Lin, C.H. Cheng, and S.S. Chen, "Developing Multimedia Instructional Material for Robotics Education,' WSEAS Trans. Commun., vol. 7, no. (11), pp. 1102-1111, 2008.

[9] Sugiyono, Metode Penelitian Pendidikan (Pendekatan Kuantitatif, Kualitatif, dan R\&D). Bandung: Penerbit Alfabeta, 2014. 